\title{
Universal History and the Origin Narrative of European Modernity: The Leiden Lectures of Jacob Perizonius (1651-1715) on Historia Universalis
}

\author{
Frederic Clark \\ Department of Classics, University of Southern California, \\ Los Angeles, CA 90089 \\ fredernc@usc.edu
}

\begin{abstract}
This article explores a central facet of humanist scholarship and pedagogy-namely, the writing and teaching of universal history - in the decades around 1700. In does so by examining one of the most prominent humanists of the European Republic of Letters: the Leiden classical scholar Jacob Perizonius (1651-1715). Through analysis of Perizonius's unpublished lectures on universal history, it explores how 'classicists' (long before they commonly identified as such) could command geographies and temporalities far distant from Greco-Roman antiquity. Late humanist classical scholars like Perizonius used the ancient genre of universal history or historia universalis to combine everything from the fall of Rome to the emergence of Renaissance Europe into a single continuous narrative. In so doing, Perizonius helped forge a via media between antiquity and modernity at a moment when self-identified "ancients" and "moderns"
\end{abstract}

* I wish to thank Mordechai Feingold for inviting me to write this article and for his generous assistance throughout the process. I am also most grateful to Anthony Grafton for his many insights into Perizonius and his expert guidance through the world of humanist scholarship. As I was finishing this article I greatly benefited from participation in a discussion group with Anton Matytsin and Thomas Wallnig on the history of early modern historiography. Aspects of this research were presented in Berlin at the Princeton-Humboldt workshop 'Ancient Knowledge in the Modern University', at the University of Amsterdam conference on the theme 'The Long Quarrel: Ancients and Moderns in the Eighteenth Century', at the annual meeting of Scientiae at St. Anne's College, Oxford, and at the annual meeting of the American Historical Association in Denver. Finally, I wish to thank the Scaliger Institute, and especially Kasper van Ommen, for generously supporting my research on Perizonius at Leiden University Library, and the two anonymous readers for Erudition and the Republic of Letters for their extremely detailed and insightful comments. 
frequently engaged in conflict. Perizonius's synthesis proved immensely influential to Enlightenment historiography and beyond. As argued here, universal history enabled Perizonius to craft an origin narrative of how nostra Europa or 'our Europe' purportedly became modern.

\section{Keywords}

historiography - universal history - classical scholarship - pedagogy - the reception of antiquity - historical periodization - book history - humanism - Enlightenment

Among the manuscripts once owned by Thomas Jefferson, now at the Library of Congress, are several volumes of commentaries upon a universal history that stretched from the Book of Genesis to the 1500 s. $^{1}$ The universal history commented upon in these volumes was composed by the sixteenth-century Italian Jesuit historian Orazio Tursellini or Horatius Tursellinus, a leading figure in his Order who taught at Rome for many years. Jefferson's reading was wide, and hence it should not surprise us that the American Deist-famous for physically excising miraculous or metaphysical content from his copy of the Gospels - possessed notes on a leading Counter-Reformation apologist. Composed in 1598, Tursellinus's Epitome of universal history soon became a staple of the Jesuit curriculum. ${ }^{2}$ It traveled across Europe in numerous editions and translations and, in so doing, also traveled far beyond its own comfort zone. By the time it migrated across the Atlantic to the third president of the infant United States, the book had experienced an afterlife that Tursellinus himself would have found unlikely, if not unthinkable.

The commentaries that Jefferson owned were deeply indebted to, but also profoundly different from, the underlying text that the Jesuit had published some two centuries earlier. They were the product of lecture notes from the classroom of the famous Dutch classical scholar Jacob Perizonius. Perizonius authored numerous historical and philological works on the ancient world, and in 1693 became Professor of Greek and Latin Eloquence at Leiden. He

1 See Washington, DC, Library of Congress MS J. 45. Cf. Catalogue of the Library of Thomas Jefferson, Vol. I, ed. E. Millicent Sowerby (Washington, DC, 1952), 22. Jefferson also owned a 1710 edition of Tursellinus's Epitome, now Library of Congress J. 44. On Jefferson's interests in ancient history, see Thomas Jefferson, the Classical World, and Early America, ed. Peter Onuf and Nicholas Cole (Charlottesville, 2011).

2 Horatius Tursellinus, Epitomae historiarum libri decem (Rome, 1598). Subsequent references are to the 1621 Cologne printing of the Epitome. 
remained an eminent figure in the pan-European Republic of Letters until his death in 1715. Perizonius did not just teach classics; for many years he also offered regular lectures on universal history, demonstrating how 'classicists' (before they self-identified as such) could command geographies and temporalities far distant from Greco-Roman antiquity. These lectures took the form of Perizonius explicating, expanding, and amending Tursellinus's Epitome, page-by-page and line-by-line. Yet the history of the Epitome's transformation covers far more ground than even the formidable distance-both literal and conceptual-that separated the Collegio Romano from Monticello. Instead, the story of this little book and its commentary stretches from late antiquity to the Enlightenment - from the world of early Christian scholars like Eusebius and Jerome to the universities of Leiden and Edinburgh, and even beyond. The Epitome even possessed an indirect connection to infant institutions of higher learning in North America. Jefferson's copy of Perizonius's commentary had formerly belonged to the Reverend Thomas Dawson, an Anglican cleric who in 1755 became the fourth president of Virginia's College of William and Mary. ${ }^{3}$ Although the precise details of its ownership history are unknown, the commentary appears to have made its way at some point from Dawson to Jefferson himself.

The case of Tursellinus and Perizonius demonstrates the deep ancient roots of what became a central feature of history curricula across the Republic of Letters - that is, the origin narrative of European modernity. There are of course many versions of this origin story, and modernity itself was an actor's category long before anyone articulated this specific tale. In the medieval world, self-identification as a 'modern' or modernus was a familiar means of distinguishing oneself from ancient predecessors. ${ }^{4}$ In the period we now define as early modern, one variation of this story grew especially popular. It posited that a new era had begun with the now familiar 'three Ps' of Petrarch, print, and Protestantism, drawing sharp and sometimes polemical distinctions between the Renaissance and a supposedly barbarous Middle Ages. Whatever its specific merits, this story may strike many today as hackneyed, or perhaps even dangerously teleological. ${ }^{5}$

3 As transcribed in Sowerby's catalogue, the first volume of the commentary contains a note that reads 'This Book containing three Volumes I give at my Death to the Revd. Mr. Tho. Dawson Rector of Bruton Parish. July the $4^{\text {th }}$ 1743. H. Potter'. See Catalogue, ed. Sowerby, 22.

4 See for instance Walter Freund, Modernus und andere Zeitbegriffe des Mittelalters (Cologne, 1957) and E.R. Curtius, European Literature and the Latin Middle Ages, trans. Willard R. Trask (New York, 1953), esp. 251-5.

5 See Frederic Clark, Dividing Time: The Making of Historical Periodization in Early Modern Europe (PhD Dissertation, Princeton University, 2014) and Frederic Clark, 'Antiquitas and the 
Yet as argued here, the origins of these origins were anything but modern. Instead, while its precedents were multiple, one fertile source of this new narrative was the ongoing transformation of the ancient genre of universal history or historia universalis. ${ }^{6}$ Historia universalis had achieved its distinctive form among late antique Christian scholars, who produced massive world chronicles extending from Creation to the present. ${ }^{7}$ Such chronicles proffered 'universality' by synchronizing the particular histories of multiple peoples or gentes, and integrating them into an overarching framework of Christian salvation history. Their very structure invited constant continuation, elaboration, and even modification. By employing one of antiquity's most malleable forms of historical writing, erudite humanist scholars helped fashion a narrative of modernity's ostensible beginnings. In doing so, they tapped into a long tradition, traceable as far back as Jerome, which used historia universalis to tell the history of what we would now term intellectual culture. ${ }^{8}$ Even before the widespread emergence of historia literaria as a distinct genre in the seventeenth

Medium Aevum: The Ancient/Medieval Divide and Italian Humanism', in Remembering the Middle Ages in Early Modern Italy, ed. Lorenzo Pericolo and Jessica Richardson (Turnhout, 2015), 19-41.

6 The bibliography on early modern universal history and its place in the history of historiography is extensive: for a selection of works that touch upon diverse areas of this vast topic, see for instance Adalbert Klempt, Die Säkularisierung der universalhistorischen Auffassung: zum Wandel des Geschichtsdenkens im 16. und 17. Jahrhundert (Göttingen, 1960), George Huppert, The Idea of Perfect History: Historical Erudition and Historical Philosophy in Renaissance France (Urbana, 1970), Donald R. Kelley, Foundations of Modern Historical Scholarship: Language, Law, and History in the French Renaissance (New York, 1970), Wilhelm Schmidt-Biggemann, Topica Universalis: Eine Modellgeschichte humanistischer und barocker Wissenschaft (Hamburg, 1983), History and the Disciplines: The Reclassification of Knowledge in Early Modern Europe, ed. Donald R. Kelley (Rochester, 1997), Joseph M. Levine, The Autonomy of History: Truth and Method from Erasmus to Gibbon (Chicago, 1999), Historia: Empiricism and Erudition in Early Modern Europe, ed. Gianna Pomata and Nancy Siraisi (Cambridge, MA, 2005), Anthony Grafton, What Was History? The Art of History in Early Modern Europe (Cambridge, 2007), Tamara Griggs, 'Universal History from Counter-Reformation to Enlightenment', Modern Intellectual History 4 (2007), 219-47, and Asaph Ben-Tov, Lutheran Humanists and Greek Antiquity: Melanchthonian Scholarship between Universal History and Pedagogy (Leiden, 2009).

7 See Anthony Grafton and Megan Williams, Christianity and the Transformation of the Book: Origen, Eusebius, and the Library of Caesarea (Cambridge, MA, 2006).

8 On Jerome's history of literature, and its use by such early Renaissance figures as Petrarch, see for instance Mark Vessey, 'Cities of the Mind: Renaissance Views of Early Christian Culture and the End of Antiquity', in A Companion to Late Antiquity, ed. Philip Rousseau (Malden, MA, 2009), 43-58, esp. $5^{\circ}$. 
century, scholars harnessed universal history to expound the seeming ebbs and flows of letters and of learning across both time and space.

Horatius Tursellinus was among those who rendered historia universalis into a history of learning. The future author of the Epitome quickly rose to prominence in the Jesuit Order. He wrote a vita of Francis Xavier, one of the founders of the Society of Jesus famous for his global proselytizing in Japan and India. ${ }^{9}$ He taught at the Collegio Romano, and in 1573 he published a guide to Latin particles, his De particulis linguae Latinae. Like his universal history, his grammar would also enjoy a far-flung circulation. It was used in German Protestant contexts, and as late as the nineteenth century the Jena classical scholar Ferdinand Gotthelf Hand produced a reworked version of the treatise that he simply titled the Tursellinus - an unlikely homage by a nineteenthcentury German scholar to a sixteenth-century Italian Jesuit. ${ }^{10}$ While Tursellinus's diverse endeavors guaranteed him an impressive afterlife, his fame rested principally upon his aforementioned 1598 Epitomae historiarum libri decem or Ten Books of an Epitome of Histories, a universal history that chronicled events from Creation until his own day.

Tursellinus published this work at a propitious time. The years around 1600 saw the production of many historical works in Catholic Italy. The most famous of these was Cardinal Cesare Baronio's massive church history, the Annales ecclesiastici, which appeared in twelve volumes between 1588 and $1607 .{ }^{11}$ Baronio was not alone in such endeavors. In 1593, just a few years before Tursellinus published his Epitome, a fellow Italian Jesuit, Antonio Possevino, released his Bibliotheca selecta, a Catholic response to the Bibliotheca universalis of the Swiss Protestant Conrad Gesner. Possevino's section on historians proved especially important, and he soon published an expanded version of it as a separate guide to historiography—his 1597 Apparatus ad omnium gentium historiam or Apparatus to the History of All Peoples..$^{12}$ As Paul Nelles has shown, historical instruction, especially in universal history, was just as important to Jesuit pedagogy as it was to the Protestant curriculum. Universal history is typically associated with the German Protestant schoolroom, owing above all to

For biographical and bibliographical details, see Jürgen Leonhardt, 'Tursellinus, Horatius', in Brill's New Pauly: Supplements 6: History of Classical Scholarship, ed. Peter Kuhlmann and Helmuth Schneider (Leiden, 2014), 622-3.

10 Ferdinand Gotthelf Hand, Tursellinus, seu de particulis Latinis commentarii (Leipzig, 1829-45). Cf. Leonhardt, 622-3.

11 Cesare Baronio, Annales ecclesiastici (Rome, 1588-1607).

12 Antonio Possevino, Apparatus ad omnium gentium historiam (Venice, 1597). On this point see Paul Nelles, 'Historia Magistra Antiquitatis: Cicero and Jesuit History Teaching', Renaissance Studies 13 (1999), 130-72, esp. 132. 
the work of Luther's associate Philipp Melanchthon, long styled the praeceptor Germaniae or 'teacher of Germany'. Melanchthon's Chronicon Carionis had made historia universalis into the foundation of Protestant historical pedagogy. ${ }^{13}$ Tursellinus showed that it had to matter for Catholic education as well.

Like Jerome over a millennium before him, who augmented his translation of Eusebius's Chronicon with entries for canonical figures in Latin literature, Tursellinus did not consider historia universalis to be only a guide to kings, popes, emperors, battles, and the like. Instead, he also included figures from the realm of learning, from poets and philosophers to theologians and historians. As Eric Cochrane observed in his survey of Renaissance Italian historiography, 'thanks to an implied definition of profane history as simply all that was not sacred history, [Tursellinus] surpassed the humanist historians in including culture along with politics as a measure of an age..$^{14}$ Of course, Tursellinus was hardly the first Italian humanist to practice a form of cultural history. His work represented a natural culmination of efforts undertaken over a century earlier by such figures as Leonardo Bruni, Lorenzo Valla, and others. ${ }^{15}$ And these efforts possessed even deeper antecedents, especially in Hellenistic and early Christian attempts at assigning founders and 'firsts' in the realm of inventions and learning — projects revived in the Renaissance most notably by Polydore Vergil. ${ }^{16}$ Still, Tursellinus did not devote the same amount of word count to the history of literature as he did to matters of church and state. Often he did nothing more than record the names of cultural figures and the dates when they had flourished. But the recitation of names-however laconic - still mattered. In Cochrane's words, it allowed Tursellinus to use learning and letters as 'measures of an age;' as we shall see, it furnished tools for the temporal contextualization of culture, and for the consolidation of a narrative of its decline and renewal.

When Tursellinus wrote his Epitome at the end of the sixteenth century, the world of European letters had absorbed a particular narrative of cultural decline and renewal. This story chronicled both the decline of learning at the end of antiquity and its triumphant revival by Renaissance humanists,

13 Philipp Melanchthon, Chronicon Carionis (Wittenberg, 1558).

14 Eric Cochrane, Historians and Historiography in the Italian Renaissance (Chicago, 1981), 456 .

15 See for example David Quint, 'Humanism and Modernity: A Reconsideration of Bruni's Dialogues', Renaissance Quarterly 38 (1985), 423-45 and Gary Ianziti, Writing History in Renaissance Italy: Leonardo Bruni and the Uses of the Past (Cambridge, MA, 2012).

16 See here Brian Copenhaver, 'The Historiography of Discovery in the Renaissance: The Sources and Composition of Polydore Vergil's De inventoribus rerum I-III', Journal of the Warburg and Courtauld Institutes 41 (1978), 192-214. 
first in Italy and then elsewhere. As Donald Kelley and others have shown, sixteenth-century French historical scholars played a key role in finessing this narrative of renewal and progress. Figures like Jean Bodin, Louis Le Roy, and Christophe Milieu argued, in varying degrees, that modernity could rival, or even surpass, its ancient counterpart. Early modern theorists also trumpeted the technological advances of their own times as proof of their superiority to antiquity, especially such inventions as the printing press, the compass, and gunpowder. ${ }^{17}$ Many likewise attributed a fundamental transformation to the intellectual culture of fourteenth- and fifteenth-century Italy. According to Milieu, for instance, who wrote a treatise on how to construct a universal history of letters, it was in 'this age' (hac aetate) - i.e., the Italian Renaissance - that learning happened 'to be reborn and renewed' (renasci renovarique). ${ }^{18}$ As we shall see, late humanists like Perizonius built upon a long tradition of comparing and contrasting the ancient and the modern, even as they defined the temporal coordinates of each with newfound specificity.

This story of cultural decline and renewal gained force as Tursellinus's Epito$m e$ was posthumously glossed. On its way from Jesuit Rome to Jeffersonian Virginia, Tursellinus's ghost passed through Perizonius's Leiden, one of Protestant Europe's premier centers of learning. ${ }^{19}$ While Perizonius is remembered as one of Leiden's leading lights, and a powerful figure in the respublica literaria of the late seventeenth and early eighteenth centuries, his contributions to universal history have been comparatively neglected. Rather, he is best remembered for his struggles against historical Pyrrhonism - the then-fashionable brand of historical skepticism that questioned whether anyone could know anything with certainty about the historical past and historical texts. Perizonius advanced a self-consciously moderate response to these challenges, not unlike the methods pioneered by the Maurist Jean Mabillon to distinguish between

17 See Roy S. Wolper, 'The Rhetoric of Gunpowder and the Idea of Progress', Journal of the History of Ideas 31 (1970), 589-98.

18 See for instance Kelley, Foundations, cited above. Christophe Milieu, De scribenda universitatis rerum historia libri quinque (Basel, 1551), 303-4: 'Protinus uero ut Italia hoc Graecorum aduentu linguam utranque coniunxit, nihil non in omni genere ad ueterum praescriptum uoluit experiri: ut cum a tenuib. rerum primordiis, per omnes aetatis hominum gradus literata atque erudita tempora fuerint progressa, hac aetate renasci renouarique contigerit'. On Milieu, see Donald R. Kelley, 'Writing Cultural History in Early Modern Europe: Christophe Milieu and His Project', Renaissance Quarterly $5^{2}$ (1999), $342-65$, especially his analysis of these discussions of renaissance at $355^{-6}$.

19 See Leiden University in the Seventeenth Century: An Exchange of Learning, ed. Th. H. Lunsingh Scheurleer and G.H.M. Posthumus Meyjes (Leiden, 1975). 
the genuine and the forged in the realm of paleography and diplomatics. ${ }^{20}$ Like Mabillon, Perizonius argued for a workable via media between absolute skepticism and absolute credulity: a pragmatic method he famously applied to the troublesome question of the historicity of the early Roman past.

While he engaged these controversies, Perizonius kept up the more pedestrian task of lecturing his Leiden students on historia universalis. Here he found an unexpected aid in Tursellinus. ${ }^{21}$ Tursellinus seems to have come to the world of Dutch pedagogy through one of Perizonius's Leiden predecessors, Johann Conrad Nuber, who also produced a new edition of the Epitome. ${ }^{22}$ It was a central, although now sometimes forgotten, feature of the early modern classroom that lectures were often not delivered ex nihilo. They frequently took the form of line-by-line commentary or exegesis upon a set text, a form of raw material from which a teacher might construct new, and sometimes oppositional, narratives. Early modern Europe was still a world of the lemma and the gloss-pedagogical methods more stereotypically associated with the cathedral schools of thirteenth-century Paris and medieval scholasticism. ${ }^{23}$ This tradition of commentary often promoted adversarial relationships between set texts and their expositors. Sometimes this was a natural byproduct of expansion. Perizonius created a far lengthier universal history by glossing individual words and phrases in Tursellinus's comparatively laconic epitome. And not least because he was a Dutch Protestant reading the work of an Italian Jesuit, he often challenged the text, saying where he thought Tursellinus had gone wrong. However, despite the occasional animosity evident in Perizonius's remarks, Tursellinus remained the author of the work, and Perizonius one of

20 On Mabillon see for instance Jan-Marco Sawilla, Antiquarianismus, Hagiographie und Historie im 17. Jahrhundert: zum Werk der Bollandisten: ein wissenschaftshistorischer Versuch (Tübingen, 2009).

21 See Nelles, 'Historia Magistra Antiquitatis', 130-72, esp. 132 for the importance of Tursellinus's epitome and its use by Perizonius. See also Johanna Roelevink, 'Lux veritatis, magistra vitae: The Teaching of History at the University of Utrecht in the Eighteenth and the Early Nineteenth Centuries', History of Universities 7 (1988), 149-74.

On Nuber and Tursellinus, see Esther Mijers, 'News from the Republick of Letters': Scottish Students, Charles Mackie and the United Provinces, 1650-1750 (Leiden, 2012), 160. See also Horatius Tursellinus, Historiarum, ab origine mundi, usque ad annum a Christo nato MDXcviII, epitomae libri decem, ed. Johann Conrad Nuber (The Hague, 1678).

23 On the importance of the commentary tradition in early modern erudition, see Transformations of the Classics via Early Modern Commentaries, ed. Karl A.E. Enenkel (Leiden, 2014). For an example of how Henry Savile constructed a history of mathematics out of his lectures upon Ptolemy, see Robert Goulding, Defending Hypatia: Ramus, Savile, and the Renaissance Rediscovery of Mathematical History (Dordrecht, 2010). On early modern textbooks, see Scholarly Knowledge: Textbooks in Early Modern Europe, ed. Emidio Campi, Simone de Angelis, Anja-Silvia Goeing and Anthony Grafton (Geneva, 2008). 
his glossators. Even when correcting him, Perizonius referred repeatedly to Tursellinus as auctor or author, without any accompanying modifiers or qualifications. The authority that the auctor Tursellinus possessed made perfect etymological sense, and when Perizonius used the term he presumably did so with full appreciation of the millennium-old exegetical tradition of glossing the auctores. ${ }^{24}$

As the unlikely partnership of Tursellinus and Perizonius demonstrates, universal history promoted a feedback loop between epitomization and abridgment on the one hand, and expansion and continuation on the other. Tursellinus had bemoaned in the preface to his book that the 'multitude and variety of histories' inhibited the study of history itself. Given the sheer number and bulk of such tomes, 'many shrink from reading histories'. Ever the pedagogue, the Jesuit proposed a remedy: 'many desire some epitome or summa of histories, where the most memorable events are treated briefly and in order (breviter atque ordine). ${ }^{25}$ He presented his universal epitome-which sought to unfold the past breviter atque ordine - as a natural response to a surplus of excessively prolix histories. Yet the action of abridgment promoted equal and opposite reactions. Commentators like Perizonius found Tursellinus's sparse outline of res gestae a perfect skeleton upon which to graft narrative flesh of their own design.

Just what was Perizonius's narrative flesh? And what is its significance to the history of historical thought? Perizonius's lectures illustrate how classical scholars, grounded in the study of the ancient past and its historiographical traditions, were uniquely positioned to fix the temporal parameters of European modernity. Theirs was a view of the longue durée that enabled both celebration and critique of the era they understood as modern. Although Perizonius certainly qualified as a classical scholar in professional terms, he demonstrated that classical scholarship in the early decades of the Enlightenment could still command the field of universal history, even its most modern phases. In fact, it

24 An important work in this vast area is Alastair J. Minnis, Medieval Theory of Authorship: Scholastic Literary Attitudes in the Later Middle Ages, $2^{\text {nd }}$ Ed. (Philadelphia, 1988).

25 Tursellinus, Epitome, preface: 'Tanta historiarum multitudo est, atque varietas, cuiusuis vt hominis non sit aut perlegere omnes, aut in ordinem redigere, aut memoria custodire. quo fit, vt complures ab historiarum lectione abhorreant, multi epitomam aliquam, ac summam historiarum desiderent. vbi res maxime memorabiles breuiter, atque ordine comprehendantur'. Perizonius was hardly the first in a long tradition of teaching history by lecturing upon historical epitomes. For the case of Degory Wheare's Oxford lectures upon Florus, see Grafton, What Was History, esp. 194-7. On Wheare see also J.H.M. Salmon, 'Precept, Example, and Truth: Degory Wheare and the Ars Historica', in The Historical Imagination in Early Modern Britain: History, Rhetoric, and Fiction, 1500-180o, ed. Donald Kelley and David Sacks (Washington, DC, 1997), 11-36. 
was the very depth of this engagement with antiquity that allowed Perizonius to construct a cultural history of modern Europe. After all, tracing modernity's origins necessitated an account of antiquity's end. And just what made Perizonius's historia universalis different from prior histories that-already in early Italian humanism - had rendered concepts like renovatio and instauratio actor's categories? For one, writing at the turn of the eighteenth century, Perizonius understood the Renaissance as a moment that was definitively past. This revival was an essential chapter in the story of how Europe became modernyet its climax had already occurred. As Perizonius and many others saw it, several centuries ago humanistic learning had successfully repelled cultural barbarism.

Second, by casting this story of revival in the past tense, Perizonius added a new and more pessimistic twist: from these formerly great heights, learning and erudition were now declining once again. Perizonius voiced these fears throughout his career, from his 1693 inaugural oration at Leiden, De usu et utilitate Graecae Romanaeque linguae... (On the Use and Utility of the Greek and Roman Language...) to his 1708 De doctrinae studiis (On the Study of Learning). In the former address, not only did he bemoan the supposed neglect of classical learning in his own day; he also spoke with nostalgic longing for a recent past now lost, defined above all by the classical scholarship of those 'most illustrious princes of letters' (illustrissimos literarum Principes), Joseph Scaliger and Claudius Salmasius. ${ }^{26}$ The rebirth of antiquity and its repulsion of barbarism were now threatened anew.

Perizonius did not raise these contemporary concerns directly in his lectures on Tursellinus's Epitome, which he ended far before his own day. Yet in his various published works, he repeatedly assumed this narrative of decline. As suggested here, these preoccupations help shed light on why Perizonius structured his universal history the way he did. As we shall see, he devoted particular attention to two aspects of the story. The first was the end of the Roman world, which Perizonius saw as marked by growing literary corruption, religious superstition, and geopolitical instability. The second was the reversal of these lamentable developments, beginning with partial recoveries in the Carolingian world and the twelfth century, and culminating in the humanist revival of classical learning, the invention of print, the birth of Protestantism, and the emergence of a new European political order. Below, we will examine

26 Jacob Perizonius, Oratio de usu et utilitate Graecae Romanaeque linguae, eloquentiae, historiae et antiquitatis in gravioribus disciplinis (Leiden, 1693), esp. 4-5. For Perizonius's views on the decline of learning in his own times from the heights marked by Scaliger and others, see Ulrich Groetsch, Hermann Samuel Reimarus (1694-1768): Classicist, Hebraist, Enlightenment Radical in Disguise (Leiden, 2015), 23-5. 
how Perizonius wove these two stories through his historia universalis. Just as history had followed an arc of decline and renewal once before-falling into barbarism only to reestablish culture-so this revival was vulnerable to the threat of barbarism's return.

This story of antiquity's end and modernity's origins is today extant in ten volumes of commentary on Tursellinus, corresponding to Perizonius's lectures on each of the ten books of the Epitome. The first three volumes dealt with matters before Christ. Volume IV stretched from Christ to the age of Constantine. In Volume v Perizonius offered a detailed treatment of Rome's decline and the emergence of postclassical Europe. The subsequent volumes surveyed the history of the Middle Ages, until Perizonius reached his tenth, and final, volume, which began in 1400 and extended to the Reformation and beyond. One of the most detailed transcriptions of these notes is preserved in ten manuscript volumes now in the Perizonius Collection of Leiden University Library. ${ }^{27}$ The volumes bear the signature of one Matthaeus Maten, one of Perizonius's countless Leiden students, who recorded that he copied down the notes over several months between 1708 and $1709 .{ }^{28}$ Although in 1710 Perizonius did publish a 'modern' continuation of this universal history, which began with events in the sixteenth century, he never printed any version of his lectures upon Tursellinus. ${ }^{29}$

However, this absence of formal publication hardly hindered the dissemination of his notes and the influence they exercised upon historical pedagogy in the eighteenth century. The Tursellinus commentaries provide a key for unlocking Perizonius's work as a whole, and for discerning a common project throughout the career of a humanist who studied such seemingly disparate topics as ancient Egypt and the modern Dutch Republic. More importantly, they promise to shed new light on the uses of history in the Republic of Letters, especially in those eventful years at the dawn of the eighteenth century.

27 I have consulted this copy, now Leiden Universiteitsbibliotheek Ms Perizonius Q 109, although there are others, including (to cite one example) a shorter and more hastily executed transcription by the Huguenot classical scholar Jacques Philippe D'Orville, who studied at Leiden and later became a professor at the University of Amsterdam. D'Orville's notes are now Bodleian Mss D'Orville 365-7. For a description of Ms Perizonius Q 109 see Codices Perizoniani (Leiden, 1946), 110.

28 For instance, the subscription at the end of Perizonius's fifth volume reads 'Finis dictatorum libri quinti, quibus finem imposuit sua manu Matthaeus Maten Ydibus Febr. anni MDCCIX'.

29 See Jacob Perizonius, Rerum per Europam maxime gestarum ab ineunte saeculo sextodecimo usque ad Caroli v. mortem commentarii historici (Leiden, 1710). Perizonius planned to publish an edition of his commentaries on Tursellinus, but for reasons unknown did not complete the project. 


\section{Perizonius, Historiography, and Classical Scholarship in the Years around 1700}

Just as Tursellinus had hoped to furnish Catholic Europe with a historical narrative to counter nascent Protestantism, so Perizonius-a hundred years later-also found himself fighting a new avant-garde. The Leiden scholar is perhaps best remembered for championing the possibility of discerning historical truth against recent assertions to the contrary by historical Pyrrhonists. $^{30}$ To some modern interpreters, Perizonius fought a losing battle. Perizonius made a cameo appearance among the vanquished in Paul Hazard's $L a$ crise de la conscience européenne, one of the most influential readings of this moment as a 'crisis'. Hazard depicted the Dutch scholar's attempts at forging a via media between credulity and skepticism as an ill-fated rear-guard action against the gathering forces of freethinking:

Perizonius hoped to salvage something at least from the great shipwreck. What was happening now to those ideas which at one time had seemed so stable and so sure? To those tenets at once so simple and so imposing? Where now were those calm and confident affirmations, those ever-fixed marks, those ever constant dates? What was one to believe? ${ }^{31}$

In more recent decades, interpretations of Perizonius's fortunes have changed. As Anthony Grafton pointed out in his treatment of one of the wilder of historical skeptics, the Jesuit Jean Hardouin, Perizonius was a significant participant in a 'regression to the cultural mean' that marked the Republic of Letters in the years around $1700 .^{32}$ More recently, in tracing Perizonius's disputes with Jean Le Clerc over the reliability of the Roman historian Quintus Curtius Rufus, author

30 The classic work on Pyrrhonism is Richard Popkin, The History of Scepticism from Erasmus to Descartes (Assen, 1960), revised as The History of Skepticism from Savonarola to Bayle: Revised and Expanded Edition (Oxford, 2003). For more recent perspectives, see for instance the essays collected in Renaissance Scepticisms, ed. Gianni Paganini and José R. Maia Neto (Dordrecht, 2009). On the interplay between Pyrrhonism and conceptions of historical truth, see Anton Matytsin, 'Historical Pyrrhonism and Historical Certainty in the Early Enlightenment', in Pour et contre le scepticisme: Théories et pratiques de l'Antiquité aux Lumières, ed. Élodie Argaud, Nawalle El Yadari, Sébastien Charles and Gianni Paganini (Paris, 2015), 243-259.

31 Paul Hazard, The Crisis of the European Mind, 1680-1715, trans. J. Lewis May (New York, 2013), 47 .

32 Anthony Grafton, 'Jean Hardouin: The Antiquary as Pariah', Journal of the Warburg and Courtauld Institutes 62 (1999), 241-67, esp. 265. 
of a history of Alexander the Great, Grafton has demonstrated that Perizonius was hardly just a hidebound opponent of Le Clerc's swashbuckling criticism. Instead, even if Le Clerc subjected writers past to high standards of verification, informed by Cartesian clear and distinct ideas, Perizonius advanced a subtle historicism that was just as forward thinking, albeit in diametrically opposed fashion. Whereas Le Clerc had faulted Curtius for his lack of historical rigor, Perizonius replied that it was wrong to judge ancient authors by presentist standards that would have made no sense in their own ancient contexts. In Grafton's words, Perizonius could seem 'as rigorously modern as Le Clerc', particularly as he 'adumbrated the historicist rejoinder' to Enlightenment claims of universal reason - a critique that would later enjoy great prominence in the nineteenth century. ${ }^{33}$

Perizonius was best known as a scholar of the ancient world who applied his moderate-minded historicizing to the question of Rome's beginnings. ${ }^{34}$ In defending Rome's origin narrative against its skeptics, Perizonius affirmed the underlying historicity of Romulus, while acknowledging that many details of the Romulus tale were fabulous. Just because it defied common sense that Romulus and his brother Remus had been nursed by a she-wolf did not imply that Romulus himself never existed. In his 1685 Animadversiones historicae, Perizonius offered a theory for how one could extract kernels of historical truth from myth and fable. ${ }^{35}$ According to his hypothesis, the earliest of Rome's historical records had been preserved not in histories proper, but rather in poetic carmina - particularly the so-called 'banquet songs' alluded to by Cicero and others. ${ }^{36}$ In the nineteenth century, the German classical scholar Barthold

33 See Grafton, What Was History, 17-18.

34 For a selection of literature that covers Perizonius and his scholarship, see for instance T.J. Meijer, Kritiek als Herwaardering: Het levenswerk van Jacob Perizonius (1651-1715) (Leiden, 1971), H.J. Erasmus, The Origins of Rome in Historiography from Petrarch to Perizonius (Assen, 1962), Peter Bietenholz, Historia and Fabula: Myths and Legends in Historical Thought from Antiquity to the Modern Age (Leiden, 1994), Arnaldo Momigliano, 'Perizonius, Niebuhr, and the Character of the Early Roman Tradition', Journal of Roman Studies 47 (1957), 104-14, Grafton, What Was History, esp. 1-20, and Fabrizio Lomonaco, New Studies on Lex Regia: Right, Philology and fides historica in Holland between the $17^{\text {th }}$ and $18^{\text {th }}$ Centuries (Bern, 2011). Perizonius is also mentioned in James Turner's recent Philology: The Forgotten Origins of the Modern Humanities (Princeton, 2014), 62.

35 Jacob Perizonius, Animadversiones historicae (Amsterdam, 1685), 202ff. Cf. Momigliano, 'Perizonius', 105 n.11. See also Jacob Perizonius, 'De historia Romuli et Romanae urbis origine', in Dissertationes septem (Leiden, 1740).

36 This theory had already been adumbrated in the sixteenth century. See Erasmus, Origins of Rome. For analysis of the sixteenth-century French humanist François Baudouin's 
Georg Niebuhr would take up this theory in earnest. As charted in a 1957 article by Arnaldo Momigliano, Niebuhr's reading of the Dutch scholar's Animadversiones also helped spawn a revival of interest in Perizonius. Momigliano pointed out that Niebuhr even sponsored a prize essay on Perizonius at the University of Bonn. ${ }^{37}$ Characterizing his enduring influence, Momigliano pithily declared that 'Perizonius worked for a via media between the pyrrhonists of his own time and the credulous traditionalists of any time. ${ }^{38}$

Perizonius was a keen reader of the Greco-Roman world. To cite but several examples, his many works included an edition and commentary on the miscellanist Aelian and a treatise on the spurious history of the Trojan War ostensibly authored by Dictys Cretensis. ${ }^{39} \mathrm{He}$ also produced more general studies of Roman culture and antiquitates, and weighed in upon the origins of another ancient civilization - that of Egypt-in his Aegyptiarum originum et temporum antiquissimorum investigatio or Investigation of the Origins and Oldest Times of the Egyptians. ${ }^{40} \mathrm{He}$ likewise examined issues of historical transition and decline - themes that played signal roles in his lectures upon Tursellinus. These interests formed a bridge between his specific studies of antiquity and his longstanding engagement with universal history—albeit any underlying distinction between the two projects would have seemed far less apparent to Perizonius and his contemporaries than it might now to us.

When addressing antiquity's decline, Perizonius told a story of political change that, even when discussing emperors and the like, never neglected literature and learning. A dissertation defended by one of Perizonius's Leiden students, one Franciscus Ellinghausen, aptly captured this duality. This short work, De praecipuis diminuti imperii Romani causis, or On the Particular Causes of the Decline of the Roman Empire, took up the question of just why and how Rome had crumbled. In so doing, it used the ancient metaphor of the life cycle, deployed by the Roman historian Florus and others, to characterize the gradual decay of Roman civilization. Specifically, it followed Florus in claiming that

treatment of Roman carmina, see Carlo Ginzburg, No Island is An Island: Four Glances at English Literature in a World Perspective (New York, 2000), 32-3.

38 Momigliano, 'Perizonius', 105.

39 See for instance Aelian, Varia historia, ed. Jacob Perizonius (Leiden, 1701), and Jacob Perizonius, 'Dissertatio de historia belli Trojani', in Dictys Cretensis et Dares Phrygius de bello et excidio Trojae (Amsterdam, 1702).

40 Jacob Perizonius, Aegyptiarum originum et temporum antiquissimorum investigatio (Leiden, 1711). Thomas Jefferson also owned a copy of this book, in addition to Perizonius's Aelian and his Animadversiones historicae. See Catalogue, ed. Sowerby, 6, 23, and 48. 
Rome descended from vigorous maturity into an age of senility. ${ }^{41}$ Yet Rome's decay was not just the product of natural cyclicality. Instead, Roman learning and culture were casualties of the disintegration of republican freedom into imperial tyranny. The dissertation bemoaned the 'fate of the liberal arts' (fatum Artium Liberalium), which were not just more neglectfully cultivated but also clearly extinguished under the emperors'. And it mournfully declared the Antonine period - the era in which, less than a century later, Edward Gibbon would begin his Decline and Fall of the Roman Empire - the 'final age of learned men' (ultima doctorum hominum aetas). ${ }^{42}$

Perizonius's scholarship extended far beyond this ultima aetas of ancient learning. His work took him well into the Middle Ages and the modern period, and his wide temporal range encouraged him to treat the classical world from a comparative perspective. Perizonius brought this comparatist spirit to his famous 1702 oration against Pyrrhonism, De fide historiarum contra Pyrrhonismum historicum or On the Credibility of Histories against Historical Pyrrhonism. ${ }^{43}$ Here he expressed his amazement that Pyrrhonists would dismiss ancient history merely because ancient texts revealed elements of the fabulous and fictive. After all, medieval Christian texts abounded with myths

41 Dissertatio philologica de praecipuis diminuti imperii Romani causis (Leiden, 1705), 13: 'In omnibus autem Imperiis ita licet natura comparatum sit, luce meridiana tamen clarius id in Republica Romana apparet, quae tanquam ingens arbor, annis confecta, vigoreque exhausta, tandem consenuit, atque exaruit, postquam Imperii fulcra, quae fortitudo, maximum gloriae certamen, sanctitas morum, et temperantia quondam fuerant, luxus et ignavia subduxerant'.

42 Dissertatio philologica, 29: 'Simile fuit fatum Artium Liberalium, quae sub Imperatoribus negligentius non modo excultae, sed et plane extinctae sunt...Inde adeo est, quod jam sub Antoninis Imperatoribus velut ultima doctorum hominum aetas fuerit. Dicendi certe Magistros, Sapientiaeque Latinae Doctores, post eos haud facile reperies. For an overview of narratives and explanations of Roman decline before Gibbon, from antiquity to the Scottish Enlightenment, see J.G.A. Pocock, Barbarism and Religion, Vol. III: The First Decline and Fall (Cambridge, 2003). Also see Alexander Demandt, Der Fall Roms: die Auflösung des römischen Reiches im Urteil der Nachwelt (Munich, 1984).

43 Jacob Perizonius, Oratio de fide historiarum contra Pyrrhonismum historicum (Leiden, 1702). On responses to Pyrrhonism, see the classic essay of Momigliano, 'Ancient History and the Antiquarian', Journal of the Warburg and Courtauld Institutes 13 (1950), 285-315. For more recent responses to and critiques of Momigliano's thesis, see Marcus Völkel, 'Historischer Pyrrhonismus und Antiquarismus-Konzeption bei Arnaldo Momigliano', Das Achtzehnte Jahrhundert 31 (2007), 179-90, and the essays collected in Momigliano and Antiquarianism: Foundations of the Modern Cultural Sciences, ed. Peter N. Miller (Toronto, 2007), especially Peter N. Miller, 'Introduction: Momigliano, Antiquarianism, and the Cultural Sciences', 3-65 and Ingo Herklotz, 'Arnaldo Momigliano's 'Ancient History and the Antiquarian': A Critical Review', 127-53. 
and fabrications as well, some of which seemed even more absurd. In short, there was something ecumenical about the office of the universal historian, who could see-when taking this long view-that all times and periods betrayed mixtures of truth and falsehood. In his words:

Nevertheless I will assert that there is almost nothing to be found in the ancient monuments of Greek and Roman history so poetical or fabulous...that you shall not discover everywhere that numerous things of the same and more absurd sort have been noted in the writings of very many monks and priests, by whom the history of the Middle Ages was largely created. ${ }^{44}$

Immersion in the long story of antiquity's transformation into the Middle Ages also encouraged Perizonius to fix the point at which the Middle Ages gave way to modernity, or what he labeled 'most recent history' (historia novissima). As discussed above, Perizonius published a modern continuation of his universal history in 1710. In his introduction, he explained why he had begun his published commentaries at the beginning of the sixteenth century, building upon themes adumbrated in his lectures on Tursellinus. For Perizonius, the European world circa 1500 betrayed a fundamental similitude with the present; at this moment an order of things emerged that was still the regnant order, and whose realities still prevailed around 1700:

You shall not more suitably deduce the course of historia novissima from any other point than from the beginning of the sixteenth century, when to such degree and through so many regions the European world (orbis Europaeus) had taken on, or soon took on, the appearance that even now prevails nearly everywhere. Therefore from this point we too will chart this history up to the death of Charles $\mathrm{V}$, in which interval we will also find the religion of the Protestants of Germany begun and established... ${ }^{45}$

44 Perizonius, De fide historiarum, 8-9: 'Vere tamen dixero, nihil ferme in antiquis rerum Graecarum Romanarumque monumentis inveniri tam poeticum aut fabulosum, nihil astu politico tam palam confictum, ad conciliandam templis, oraculis, sacerdotiis, praecipuam quandam auctoritatem, aut ad celebrandas miraculis quibusdam victorias, quin complura ejusdem et absurdioris etiam notae in scriptis Monachorum et plerorumque Sacerdotum, a quibus Historia sequioris aevi maximam est partem profecta, deprehendas passim'. Perizonius here refers to the Middle Ages as the sequius aevum, an alternate name for the period found in other examples of late humanist scholarship. See Clark, Dividing Time, 180.

45 Perizonius, Commentarii historici, 1: 'Haud aliunde commodius deducas seriem Historiae Novissimae, quam ab Saeculi Sextidecimi initio, quando Orbis Europaeus per plerasque 
Enumerating themes that would go on to populate many a European history survey course, Perizonius tied the onset of historia novissima to developments both political and religious, from the rise of centralizing monarchies to the birth of Protestantism. In addition, he catalogued other epochal changes that (in his view) distinguished the sixteenth century from its predecessors, such as the Spanish colonization of the Americas and the conflicts that led ultimately to the establishment of the Dutch Republic. Nor was Perizonius a stranger to the politics that marked his vision of historia novissima, and had guaranteed his country a place in it. He taught a separate course-labeled historia patria - on the history of the Netherlands. And he composed a eulogy upon the death of England's Queen Mary, wife of William of Orange, with whom he had been acquainted during her time in the Netherlands. ${ }^{46}$ Given Perizonius's admiration of Mary, it is all the more fitting that, as noted at the beginning of this essay, his universal history lectures entered Thomas Jefferson's library via a future president of the Virginian college that bore her name.

Perizonius's commentaries also travelled closer to home. As Esther Mijers has shown, thanks to the numerous Scottish students who attended Dutch universities, many elements of Dutch education made their way to Scotland, where they influenced the new history curricula of the eighteenth century. Mijers has documented in particular how Charles Mackie, who later held the first chair in history at the University of Edinburgh, studied universal history at Leiden under Perizonius's successor, Pieter Burman. Burman's universal history course followed Perizonius's outline and likewise took the form of commentary upon Tursellinus. Once he assumed his post at Edinburgh, Mackie similarly offered a course on universal history based upon Tursellinus and his Dutch commentators. ${ }^{47}$ Here it is worth pondering the specific pedagogic traditions that may have linked Perizonian historia universalis to Enlightenment stadial theory and philosophical history. Indeed, among Mackie's many students was none other than William Robertson, one of the most influential of Enlightenment historians. In addition to penning histories of Scotland and America, Robertson also composed a history of the reign of Charles $\mathrm{v}$, a period

regiones vel tantum quod acceperat, vel mox accepit, eam rerum faciem, quam etiam nunc ferme ubique obtinet. Inde ergo et nos progressi, rem persequemur usque ad Caroli v. mortem, quo intervallo Religio quoque Protestantium Germaniae reperietur coepta et constituta, ac publicis legibus munita, immo et in suas iterum partes distracta'. Jacob Perizonius, Laudatio funebris Mariae II (Leiden, 1695). On Mary's connections to Perizonius and other Dutch humanist scholars, see Melinda Zook, 'A Latitudinarian Queen: Mary II and Her Churchmen', in Religion and Women in Britain, c.1660-1760, ed. Sarah Apetrei and Hannah Smith (Farnham, 2014), 99-115. 
that he identified, as Perizonius had done before him, as the origin of European modernity. 48

As explored below, Perizonius's version of historia universalis adumbrated Enlightenment accounts of the rise of the modern European order, even if it differed in key respects from later eighteenth-century 'philosophical histories' that remain far better known today. The Dutch classical scholar occupied a neglected temporal middle ground between humanism and Enlightenment. Leiden around 1700 proved a crucial stopping point between Tursellinus's Rome of 1600 on the one hand, and Robertson's Edinburgh of 1750 - or even Jefferson's Virginia of 1800 - on the other. In what follows, we will analyze Perizonius's universal history lectures in detail, especially his characterization of the end of antiquity and the beginning of modernity.

\section{Decline and Fall: Perizonius from Antiquity to the Middle Ages}

If Perizonius saw much of universal history as a story of decline, he was clear about the cultural heights from which it had fallen. Like many a humanist historian before him, Perizonius found his Golden Age in the Rome of Cicero and Augustus. And his vision of this Golden Age shaped his views of the vicissitudes of history both distant and recent. Just as cultural decline had happened long ago, so it was perhaps happening once again. In 1708, Perizonius delivered his Oratio de doctrinae studiis, nuper post depulsam Barbariem diligentissime denuo cultis et desideratis, nunc vero rursus neglectis fere et contemptis or Oration on the Study of Learning, recently honored and diligently sought after anew after the expulsion of barbarism, and now scorned and almost neglected once again. The cyclical chronology advertised in his oration's ponderous long title said it all. Ancient learning had been destroyed by barbarism, but was cultivated anew after barbarism's successful repulsion. The present day threatened a return to barbarism, as learning was 'again' (rursus) neglected. In condensed form, Perizonius's oration surveyed the themes of renewal and decline that he also explicated throughout his universal history lectures.

In the opening pages of his De doctrinae studiis, Perizonius celebrated Augustan Rome for both the quality and wide dissemination of its learning. From the city of Rome, learning 'scattered its light as widely as possible'. Perizonius traced its path according to traditional notions of translatio studii: the Romans

48 William Robertson, The Progress of Society in Europe: A Historical Outline from the Subversion of the Roman Empire to the Beginning of the Sixteenth Century, ed. Felix Gilbert (Chicago, 1972). 
had absorbed their erudition from the Greeks, and would in turn transmit it to the gentes, especially those beyond the Alps. ${ }^{49}$ But political changes in Rome itself arrested the progress of the arts and letters: 'the power of the Caesars degenerated into the gravest tyranny'. At the same time, 'all good arts (omnes bonae artes)...began to be destroyed little by little, or were forced into silence'.50

In manuscript notes he compiled on the subject of ecclesiastical history, Perizonius linked this zenith of the artes to some of the oldest tropes of historia universalis - namely, the felicitous conjunction between Christ's birth and the pax Augusta, and the role of Augustan unity in facilitating the spread of Christianity. Perizonius marveled that up to this time no monarchy had arisen that was 'vaster or wider than the Roman'. Again, he invoked Florus's characterization of the Augustan age as Rome's 'robust maturity'. But the pax Augusta was not just a political phenomenon. The Roman world enjoyed a common peace and common laws, but it also enjoyed something more: common artes liberales. Perizonius marveled at how the liberal arts and the languages in which they were handed down' traveled throughout Rome's vast empire. This promoted the spread of the Gospels across great distances. As he added, 'Greek was then the common language of all learning (omnis eruditionis), and indeed of almost the whole world.51

49 Jacob Perizonius, Oratio de doctrinae studiis, nuper post depulsam Barbariem diligentissime denuo cultis et desideratis, nunc vero rursus neglectis fere et contemptis (Leiden, 1708), 10: 'Floruerunt olim in Italia et Urbe Roma, Ciceronis atque Imp. Augusti potissimum temporibus, variae Eruditionis studia majorem in modum, lumenque suum sparserunt inde quam potest latissime. Acceperant ea Romani a Graecis, et vicissim in Gentes ab se devictas, ac Transalpinas maxime, propagarunt ipsi'.

50 Perizonius, De doctrinae studiis, 10: 'Sed desciscente tandem Caesarum potentia in tyrannidem gravissimam, sicuti omnes bonae artes, sic et ipsa ingenia paulatim deleri aut in silentium cogi coeperunt'.

$5^{1}$ Leiden Universiteitsbibliotheek Ms Perizonius Q 106, fol.gor: 'Sed tam multo vastius et amplius erat Imperium Romanum, adeo ut ad hoc usque tempus nulla unquam exstiterit Monarchia, quam fuerit vastior aut latior quam Romana! ...Hinc Florus in praefatione ubi assimilat imperium R. homini, et dividit per 4 hominum aetates, Augusti seculum ipsam imperii iuventam et quandam q[uasi] robustam maturitatem vocat, quum post Augustum consenuerit. Liquet ergo ex his quod nunquam alias maxima pars orbis Terrarum tam communi vineulo unius veluti Reip. constricta et coniuncta fuerit, quum omnes regiones Imperio R. subiectae sibi invicem paterent, tanquam communi pace et legibus utentes. Sed accessit aliud notabile item instrumentum communis commercii inter homines et proinde et propagationis Evangelii per orbem Terrarum, quod nempe una cum legibus et imperio Romanorum propagabantur et artes liberales, et linguae quibus illae tradebantur...Etenim Graeca erat tunc communis lingua omnis eruditionis, immo totius pene Terrarum Orbis'. For a description of the manuscript, see Codices Perizoniani, 108-9. 
In his lectures on Tursellinus, Perizonius explored in detail the metamorphosis of Roman imperium in the centuries following the pax Augusta. He devoted particular attention to Christianity's transformation of the Roman world. This proved one of the most important themes in the latter volumes of his commentaries - and a fertile source of disagreement with Tursellinus. For instance, in an especially lengthy gloss he challenged Tursellinus's reference to the apostle Peter's links with Rome. Although Perizonius adopted an entirely predictable Protestant position, he based his rejection of the traditional Catholic account of Peter's founding of the Roman Church upon the political differences between late antiquity and antiquity proper. As he saw it, Peter's presence at Rome was a fable (fabula) only invented in the fourth century after Christ'. This confabulation was a direct response to new realities. After Constantine established his capital at Constantinople, Rome was no longer the sole center of the empire, and hence required a new pretext for asserting its ecclesiastical supremacy. As a result, so Perizonius claimed, it began to claim primacy via connection to Peter.

To Perizonius, Christ's statement that 'you are Peter, and upon this rock I will build the church' had nothing to do with the apostolic succession claimed by the bishops of Rome. Rather, 'Peter was never at Rome,' and if one were to read Christ's statement in such a light, if anything it accorded primacy to Jerusalem, 'for this church had been founded by Christ himself', ${ }^{22}$ Perizonius's denial of the historicity of Petrine apostolic succession is hardly surprising. Yet of far more importance to his conception of historia universalis is the manner in which he read Rome's claims regarding Peter as a reaction to the complex geopolitics of late antiquity — and proof that religion and politics were inextricably tied to one another.

52 Leiden ms Perizonius Q 109, Vol. IV, 4-5: 'Petro: Fabula haec demum inventa saeculo quarto post N.C. Etenim Roma quia erat metropolis Imperii, episcopus Romanus etiam primum locum inter reliquos habebat, sed cum Constantinopolis Romae aequalis iam esset facta, Imperio diviso in Orientale et Occidentale, imo superior tum episcopus Constantin: volebat primum locum tenere, quem ante habuerat Romanus eandem ob causam, sc. quia sua urbs iam esset metropolis, quare tum Romanus episcopus in 4to concilio universali Chalcedonensi, alia adhibuit nova, et hactenus nondum allata argumenta, se sc. et successorem Petri, qui princeps apostolorum constituitur iis verbis, Tu es Petre, et in hac petra ecclesiam aedificabo, quibus etiam effecit, rudibus iam temporibus, ut primus manserit, sed 1. locus ille huc non pertinet. 2. Petrus Romae nunquam fuit. 3. Vanum erat hoc argumentum, nam ita episcopo Hierosolymitano primatus competiisset, nam haec ecclesia a Christo ipso erat condita'. For Tursellinus's reference to Peter and Paul in his section on the emperor Nero, see Tursellinus, Epitome, 146: 'Itaque Petrum, et Paulum Apostolorum principes, Simonis Magi interitu accensus, morte multauit'. 
Beyond the realm of confessional dispute, Perizonius critiqued Tursellinus for failing to grasp the changing contours of the late antique world - the very world that had spawned the kind of historica universalis he and Tursellinus still practiced. At the start of Volume $\mathrm{v}$ of his commentary, he chastised the Jesuit for not dividing his history properly, and hence minimizing one of late antiquity's main historical turning points. Tursellinus had begun the fifth book of his Epitome with an account of Constantine's co-emperor Licinius. Yet it was not until 324 that Constantine, having defeated Licinius, became sole emperor. Perizonius saw this as a significant milestone that merited better reflection in the structure of Tursellinus's text. As he told his students, 'the author deployed this division badly, for he ought to have begun a new book from that time when Constantine alone possessed [the whole empire]. ${ }^{53}$

Although Perizonius described late antiquity as a time of momentous transformation, he also characterized its changes as gradual. Constantine had not changed the old world in an instant- - even if Rome's first Christian emperor had quite literally inaugurated a new chapter of historia universalis. Instead, Perizonius insisted upon a slow, complex transition from paganism to Christianity: 'all paganism did not perish in an instant, for the Temple of Vesta remained with its vestal virgins, and there were many celebrated pagans, because [paganism] flourished all the way to the era of Arcadius and Honorius. ${ }^{54}$ Later, Perizonius used a biographical gloss to demonstrate the coexistence of Christianity and paganism. Explicating Tursellinus's reference to the late fourth-century statesman and man of letters Quintus Aurelius Symmachus, he observed, 'at this time lived Symmachus, the prefect of the city of Rome. Although he was a pagan, in these times there were still pagans in the Senate and in other public offices.55 Perizonius then related how Symmachus had petitioned the emperor Gratian to preserve such pagan institutions and symbols as the Vestal Virgins and the Altar of Victory, but was later opposed by both Ambrose, bishop of Milan, and the Christian poet Prudentius.

53 Leiden ms Perizonius Q 109, Vol. v, 1: 'Male hanc divisionem rerum adhibuit auctor. Debuerat enim novum librum incipere ab eo tempore, quo Constantinus omnia tenuit solus'.

54 Leiden ms Perizonius Q 109, Vol. v, 6: 'Verum non statim omnis periit gentilismus, nam mansit templum Vestae cum virginibus Vestalibus, et multi etiam gentiles celebres, quod duravit ad Arcadii et Honorii usque tempora'.

55 Leiden ms Perizonius Q 109, Vol. v, 43: 'H.T. vixit Symmachus praefectus urbis Romae, gentilis tamen, uti his adhuc temporibus in senatu aliisque publicis dignitatibus erant gentiles, qui libello supplice a Gratiano petebat, ut Virgines Vestales et ara Victoriae, antea ad curiam stans, restituerentur, sed scripserunt contra hunc Ambrosius et Prudentius Poeta Christianus'. 
If pagan literati like Symmachus showcased the gradual nature of Christianity's triumph in the wider world, their Christian counterparts demonstrated the onset of corruption within Christianity itself. The Leiden scholar found in late antiquity the origins of Christian superstitio - itself a central component of Protestant historical narrative since as early as the sixteenth century. For instance, his entry for one of Symmachus's principal Christian antagonists, the aforementioned Prudentius, declared him 'a poet and a theologian, who celebrated the saints and the martyrs in his verses, since superstition was already then beginning. ${ }^{56}$ As superstition rose, letters declined - exhibiting a marked descent from the flourishing artes liberales of the Augustan age. When he glossed Tursellinus's reference to the poet Claudian, who flourished in the years around 400 , Perizonius characterized him as 'a great Christian poet'. Yet Claudian was 'not useful for students to read,' given his 'exceedingly turgid' style. ${ }^{57}$

Perizonius's narrative of the rise of superstitious, and seemingly pagan, elements in Christianity-especially ostensibly polytheistic practices like the cult of the saints - found oblique expression in his digression on the origins of the term paganus itself. Perizonius noted that pagani, which originally referred to rustics, eventually replaced such earlier labels as gentiles (gentiles) or heathens (ethnici): 'Some think that Christianity gained strength earlier in the cities, and because the rustics had stayed pagans the longest-just as in the Reformation very many rustics would remain papists, and remain so still—so they think paganus came to denote a pagan. ${ }^{58}$ Through this aside, Perizonius drew an invidious comparison between late antique paganism and early modern Catholicism. Thereafter, he attributed the veneration of martyrs's relics to the misunderstanding of the 'rude people' or rudis plebs. ${ }^{59}$

56 Leiden ms Perizonius Q 109, Vol. v, 57: 'Prudentio: Poeta Theologus, carminibus celebrans Martyres et sanctos superstitione jam tum incipiente, defendit etiam religionem Christianam contra Symmachum praefectum urbis'.

57 Leiden ms Perizonius Q 109, Vol. v, 57: 'Claudiano. Poeta Christianus magnus, tyronibus tamen lectu inutilis, quia stylo nimis est turgido, historias superioris paulo temporis descripsit, ut de Ruffino, Eutropio aliisque in aula Arcadii vel Honorii, cum duabus filiabus Stiliconis'. On debates over Claudian's religious affinities in humanist scholarship, including questions regarding whether the poet was Christian, see Clark, Dividing Time, 78-81.

$5^{8}$ Leiden ms Perizonius Q 109, Vol. v, 6: 'Ortum autem est H.T. nomen Paganorum, cum antea gentiles, vel Ethnici dicebantur: sed inde disputatur. Quidam putant prius in urbibus invaluisse Christianismum, et quod rustici diutissime gentiles manserant, uti in generali reformatione rustici plurimi permanserint Pontificii et adhuc sint, unde putant paganum notasse gentilem. Cf. Tursellinus, Epitome, 192.

59 Leiden ms Perizonius Q 109, Vol. v, 7: 'Ab his autem ossibus martyrum illatis templa vocabantur Martyria; concionatores autem laudantes eos more Rhetorico eos 
One can only imagine how Tursellinus himself would have responded to such remarks.

Whereas Perizonius lamented the introduction of pagan superstition into Christian religion, he spoke positively of the final chapters in the history of Greco-Roman paganism. His glosses reveal a surprisingly sympathetic treatment of the emperor Julian the Apostate, who had restored pagan worship several decades after Constantine's conversion. He characterized the pagan Julian as blameless both in his public and his private life. He exhibited neither cruelty, nor drunkenness, nor lust, but 'lived austerely in a philosophical manner'. As Perizonius concluded, Julian 'wished to show that one could possess the most upright morals through pagan philosophy'.60 While unlettered Christians sank into superstitious veneration of saints and relics, a defiant pagan emperor practiced virtuous austerity and philosophical simplicity.

Perizonius did not have nice words for the emperors who followed Julian just several decades later. He deemed Arcadius and Honorius, the sons and successors of Theodosius I, 'plainly stupid, for which reason they greatly incapacitated the whole empire'. Utilizing a comparatively conservative form of exegesis that read history as a storehouse of exempla, he then drew a political object lesson, declaring, 'here we again have an example of how paternal virtue might not transfer to one's sons'.61 And here, at the beginning of the fifth century, Perizonius set the stage for the final drama of Rome's demise, while taking Tursellinus to task for not having gotten the intricacies of this history correct. When glossing the general Gildo, who rose up against Honorius, he lamented that 'this history is complex, and it is not accurately narrated by the author' ${ }^{62} \mathrm{~A}$ few pages later, he highlighted the tristis status or 'sad condition' of the Roman Empire, now rocked by barbarian invasions on its borders. ${ }^{63}$

alloquebantur saepe, unde rudis plebs persuasit dein sibi eos revera audire, unde tandem adoratio'.

6o Leiden ms Perizonius Q 109, Vol. v, 24: 'Nulla tamen in eo vitia fuere publica aut privata, nec crudelis, nec ebriosus, nec venereus fuit, sed austere vivebat more philosophico... videtur voluisse ostendere, mores etiam probatissimos posse haberi per gentilem philosophiam'. Julian's probity was celebrated most programmatically, and not without controversy, in Edward Gibbon's Decline and Fall of the Roman Empire.

61 Leiden ms Perizonius Q 109, Vol. v, 45: 'Stupidi plane erant, unde totum Imperium valde debilitarunt. Habemus hic iterum exemplum, quomodo paterna virtus non transeat ad filios'.

62 Leiden ms Perizonius Q 109, Vol. v, 45: 'Intricata haec est historia, nec accurate ab auctore narrata'.

63 Leiden ms Perizonius Q 109, Vol. v, 54: 'Vandali: Tristis status erat Imperii Rom. ab omnibus barbaris invasi, Suevi erant ex Germania orti, Vandali et Alani versus Poloniam et Hungariam <illegible> invaserunt Germaniam inferiorem'. 
In his sixth book of commentary, Perizonius arrived at the early Middle Ages and the new world that followed the collapse of Roman power in the West. Now more than halfway through his lectures, he continued to unfold a narrative of rising superstition and barbarism. For example, he bemoaned the state of early medieval historical writing, and remarked in his gloss on the sixthcentury Frankish historian Gregory of Tours that Gregory had sullied his history of the Franks with 'absurd fables'.64 Perizonius's critique echoed his point in De fide historiarum: the Middle Ages were replete with fabulous myths and credulous readers. Earlier in his lectures he had addressed one of these early medieval fables-although one not invoked by Gregory - namely, the supposed Trojan origins of the Franks. As might be expected, Perizonius treated these claims with skepticism. But unlike other debunkings of such legends, he added a motive. He suggested that the Franks had traced their lineage to Troy, as had so many other medieval gentes, in imitation of Rome's own origin story. And even if the Frankish Troy story were false, Perizonius did not embrace any alternative as the definitive true historia. As in his more famous treatment of early Roman history, Perizonius refused to pass easy judgments. Instead, twice in his gloss he deemed the actual origins of the Franks 'uncertain' (incerta). ${ }^{65}$

Although credulity and corruption abounded in Perizonius's Middle Ages, he repeatedly acknowledged positive signs of medieval learning —or at least what he judged had counted as learning by medieval standards. To cite several examples, he characterized the Northumbrian monk Bede as an 'orator, rhetor, poet, historian, and theologian, clearly most learned by the standard of his time' (doctissimus pro ratione illius temporis). ${ }^{66} \mathrm{He}$ deemed the writings of the Carolingian scholar Rhabanus Maurus 'erudite enough (satis erudita) for his time' and the tenth-century monk Widukind of Corvey a 'celebrated and accurate enough (satis accuratus) writer' about Otto and the Saxons. ${ }^{67}$ Perizonius

64 Leiden Ms Perizonius Q 109, Vol. vI, 49-50: 'Erat autem Gregorius episcopus Turonensis scripsit res Francicas, sed immixtis absurdis fabulis'.

65 Leiden Ms Perizonius Q 109, Vol. v, 61: 'Verum origo eorum incerta: Iactant quidam diruta Troja Trojanos quosdam iuxta Pontum Euxinum consedisse, indeque in Pannoniam transuisse, inde in Germaniam venisse, ubi condiderunt Franconiam, sed incerta plane haec sunt, et ad imitationem Romanorum cum tot aliis populis a Trojanis orti videri voluerunt'.

66 Leiden ms Perizonius Q 109, Vol. vi, 77: 'Beda. Erat hic Orator, Rhetor, Poeta, Historicus, Theologus sane doctissimus pro ratione illius temporis. Narrant eum caecum fuisse, tumquem ab aliis deductum ad acervum lapidum, quasi ad infideles homines convertendos, sed tum vox audita est ex eo: $\underline{\text { Ita est venerabilis Beda, hinc vulgo dicitur Venerabilis }}$ Beda'.

67 Leiden Ms Perizonius Q 109, Vol. viI, 12: 'Rabanus abbas fuit Fuldensis, cognomine Maurus, dein Archiepiscopus Moguntinus et primus doctor in schola Parasina [sic]. Supersunt eius scripta prae eo tempore satis erudita'. 
found reason for the continued flourishing of some-albeit compromisederudition in the fragmentary survival of the physical remnants of GrecoRoman culture. He commented several times upon the preservation of ancient texts in medieval manuscripts and the library collections that housed them. For instance, he informed his students of the monastic library at Widukind's house of Corvey, and of the plures scriptores or 'many writers' it preserved from oblivion. As he exclaimed, 'afterwards a part of the history of Livy was discovered here, which was never elsewhere'. ${ }^{68}$ This insistence that the bonae artes never wholly disappeared would inform Perizonius's subsequent treatments of the Renaissance and modern cultural renewal.

Like many humanist historians before him, Perizonius dwelled at length upon the Carolingian epoch, reading it as a key moment in the emergence of modern Europe out of the ruins of the old Roman world. In his words, Charlemagne introduced 'the greatest change (mutatio) of affairs into our Europe (nostram Europam)'. This vision of a collective, possessive nostra Europa anticipated Perizonius's aforementioned allusion to the orbis Europaeus, offered in the introduction to his historia novissima. Perizonius's idea of a new European order under Charlemagne prompted him to look outwards as well. He remarked to his students that here we must consider the state of the whole world, which was divided at that time into three great empires (tria magna Imperia)' - i.e., the Latin, Byzantine, and Islamic. ${ }^{69}$

The Leiden scholar approached Charlemagne's Latin empire with ambivalence. Charlemagne, so he noted, was a 'lover of women,' who possessed multiple wives and concubines. Nor did this meet with societal condemnation;

68 Leiden ms Perizonius Q 109, Vol. viI, 103: 'Wittichindus: scriptor celebris et satis accuratus scripsit res Saxonicas et vitam Othonis, fuit ille abbas Corbicensis in Westphalia, ex quo monasterio plures prodiere scriptores. Fuit in eodem <illegible > egregia bibliotheca, in qua postea pars Livianae historiae reperta est, quae nusquam alibi'.

69 Leiden ms Perizonius Q 109, Vol. viI, 1: 'Distinguit auctor vitam Caroli nondum coronati, et iam a Leone coronati, quam hoc libro incipit. Considerat enim iam post coronationem papae eum demum legitimum imperatorem, uti et barbaris illis temporibus Imperatorem nondum putabant a populo electum, sed a papa coronatum, et ita approbatum; verum iam eam coronationem negligunt: Nam post Carolum quintum nemo amplius a papa est coronatus. Ab hoc Carolo maxima rerum mutatio inducta est in nostram Europam. Considerandus hic est totius terrarum orbis status, qui hoc tempore divisus fuit in tria magna Imperia'. Perizonius then went on to discuss the components and characteristics of each of these three empires. For one of many examples of sixteenth-century sources that discussed the Carolingian world in such revolutionary terms, see for instance Gilbert Génébrard, Chronographiae libri quatuor (Paris, 1580), 293. 
according to Perizonius, 'these deeds did not cause much worry at that time, because religion was plainly just ritual. ${ }^{70}$ In the very next paragraph, Perizonius affirmed that Charlemagne was also a 'devotee of letters and men of letters'. But there were real limits to such learning. Again Perizonius deployed his favored adverb for characterizing medieval learning-namely, satis or 'enough' - when speaking of Charlemagne's own attainments: 'He himself was erudite enough (satis eruditus), but he was not able to write. For nobles in that [time of] barbarism left it to clerics to write and study'.71 Yet whatever his criticisms of medieval religion and clericalism, he still distinguished it from the ultramontane nature of future Catholicism. Discussing debates over iconoclasm in the Carolingian world, he observed that the papacy had not yet established doctrinal supremacy: 'from this it is clear that all the churches of the West did not yet then think that the pope had authority in matters of faith and religion. 72

At the end of his survey of the Carolingian world, Perizonius added a note that began with the phrase huc addenda or 'here must be added'. These words signaled that he was momentarily putting aside his normal task of glossing Tursellinus, and wished to speak of a matter significant enough to merit discussion even if Tursellinus had not treated it in the Epitome. Here Perizonius told his students of the Norman invasions that occurred under Louis the Pious, and which saw the Normans move down from Denmark and Jutland and strike at both England and France. As he explained, around the time of Louis's death, the Normans invaded France, whereupon they 'destroyed and burned various cities'. Yet most notable about his digression was the language he used to characterize this new geopolitical reality. Just as he had earlier spoken of a mutatio, now he spoke of a revolutio. Thanks to the Normans, 'a marked revolution (insignis revolutio) occurred in this our Europe (hac nostra Europa)'. Hence, twice in his history of the eighth and ninth centuries he invoked 'our Europe' or nostra Europa, a new entity that had emerged from the ruins of the old Roman order. ${ }^{73}$ Perizonius was now far from the world of the pax Augusta

70 Leiden Ms Perizonius Q 109, Vol. VII, 2: 'Carolus Magnus amator fuit foeminarum, tres legitimas uxores habuit, et 8 concubinas, ex quarum una filiam habuit, quae valde impudice vixit, nec talia facta H.T. multum curabantur, nam religio plane ritualis erat'.

71 Leiden ms Perizonius Q 109, Vol. viI, 2: 'Carolus Magnus amabat literas et literatos homines; ipse satis eruditus fuit; sed scribere non potuit; nam nobiles in hac barbarie scribere et studere Clericis relinquebant'.

72 Leiden ms Perizonius Q 109, Vol. viI, 23: 'Hinc patet Ecclesias Occidentis omnes nondum tum putasse, papam habere auctoritatem in rebus fidei et religionis'.

73 Leiden ms Perizonius Q 109, Vol.viI, 30-1: 'Huc addenda: H.T. et maxime sub hoc Ludovico Pio insignis revolutio contigit in hac nostra Europa. Iam sub Carolo M. Normanni 
and the flourishing learning he had ascribed to it. Barbarism, superstition, and political upheaval had destroyed this old world, even if they had not completely annihilated learning itself. In the remaining volumes of his commentary, he constructed a narrative of how nostra Europa revived antiquity's artes liberales, and in doing so became modern.

\section{Rebirth and Renewal: Perizonius from the Middle Ages to Modernity}

When Perizonius turned to the latter half of the Middle Ages, he dwelled at length upon harbingers of renaissance and revival, especially from the twelfth century onwards. ${ }^{74}$ For Perizonius, the darkest of the dark ages seems to have corresponded to the centuries immediately after the fall of Rome, whereas the twelfth century and beyond began to exhibit renewed signs of light. While they did not explicitly identify these moments as medieval renaissances, late

Frisiam et Galliae littora invaserant, sed ab eo repulsi fuerunt, sub Ludovico Pio idem perseverarunt, sed non adeo graviter; primi eorum prodierant ex Jutlandia et Dania ac Galliam invaserant. Tum anno 793 Angliam invaserant. Offa rege Merciae, incursionem in Northumbriam fecerunt. Circa mortem Ludovici invaserunt Galliam per Ligerum flumen vastarunt et incenderunt varias urbes... For a sixteenth-century use of the term nostra Europa in the context of universal history, see François Baudouin, De historia universa, in Artis historicae penus, ed. Johannes Wolf (Basel, 1579), 662: 'Quid ergo interea nostra Europa? Non est iam necesse pluribus verbis dicere, quantum infelix elaborarit, ut cum magna literarum, doctorumque hominum penuria laboraret, tamen res suas ab oblivione vindicaret'. On Baudouin's call for a universal history that would go beyond nostra Europa, see Donald R. Kelley, 'Historia Integra: François Baudouin and His Conception of History', Journal of the History of Ideas 25 (1964): 35-57, esp. 53.

74 The literature on early modern approaches to the Middle Ages is extensive: for a selection that crosses geographic and confessional contexts, see for instance Nathan Edelman, Attitudes of Seventeenth-Century France towards the Middle Ages (New York, 1946), Lionel Gossman, Medievalism and the Ideologies of Enlightenment: The World and Work of La Curne de Sainte-Palaye. (Baltimore, 1968), Frank Borchardt, German Antiquity in Renaissance Myth (Baltimore, 1971), Siân Echard, Printing the Middle Ages (Philadelphia, 2008), and Peter Miller, 'Peiresc's History of Provence: Antiquarianism and the Discovery of a Medieval Mediterranean', Transactions of the American Philosophical Society 101 (2011), 1-98. For a context closer to Perizonius's own world, see Anton J. Rinzema, 'Groninger hoogleraren uit de periode 1614-1876 en hun belangstelling voor de geschiedenis der middeleeuwen', in De Geschiedenis van de Middeleeuwen aan de Groningse Universiteit, 1614-1939, ed. Catrien Santing (Hilversum, 1997), 11-38. 
humanist scholars helped plant the seeds of such interpretations. ${ }^{75}$ This is reflected in an ambiguous refrain that Perizonius deployed with several variations throughout his works - namely, his observation that culture and letters began 'to revive a little' or reviviscere aliquantulum. Such understatementperhaps mixed with slight surprise - captures just how ambivalently humanists assessed the transition from the Middle Ages to modernity. Renewal had begun, but only in halting fashion.

Perizonius began his narrative of partial intellectual revival by telling another story of an ancient text's recovery, just as he had earlier mentioned the Livy manuscript sheltered at Corvey. When glossing Tursellinus's mention of ius civile or Roman civil law, Perizonius offered a lengthy note on the eleventhcentury rediscovery of the famous copy of Justinian's pandects at Amalfi. He credited this felicitous find-later transferred to Pisa and thence to Florence-with a renewed flourishing of legal studies. But this revival of antiquity was incomplete. At this moment, 'jurisprudence and other sciences began to revive a little' (reviviscere coeperunt aliquantulum). Yet as practiced in the eleventh and twelfth centuries, these disciplines were still obscured by the 'greatest darkness', since 'the study of letters was not yet thriving. ${ }^{76}$ It would require a full-scale rebirth of letters - as had once flourished in the age of Cicero and Augustus, and which Charlemagne had esteemed but failed to master-in order to revive culture writ large. Renaissance would have to wait a few more centuries to see its full fruition. Nevertheless, medieval developments in the history of learning deserved praise: far from comprising a step backwards, they represented a movement in the right direction, formidable darkness notwithstanding. At the close of his eighth volume, which concluded with the end of the thirteenth century, Perizonius again departed from Tursellinus's script

75 For one of the most programmatic articulations of this view in the early twentieth century, see Charles Homer Haskins, The Renaissance of the Twelfth Century (Cambridge, MA, 1927). See also Renaissances before the Renaissance: Cultural Revivals of Late Antiquity and the Middle Ages, ed. Warren Treadgold (Stanford, 1984).

${ }_{76}$ Leiden ms Perizonius Q 109, Vol. viII, 48: 'Ius civile: Iurisprudentia, aliaeque scientiae H.T. reviviscere coeperunt aliquantulum, sed maxima caligine adhuc abdictae nondum vigentibus literarum studiis; Bononienses tradunt H.T. ius civile doceri in sua urbe, res est incerta, sicuti Conringius ostendit, qui ea de re scripsit, certum hoc est, quod H.T. egregium illud exemplar Pandectarum inventum sit in urbe Amalphitana capta per Imperatorem Lotharum, et Rogerio adempta; cum tale exemplar in hac urbe inveniretur, donatum est Pisanis propter operam bene gestam, quam utilem praestiterant in eius urbis obsidione; post autem cum Florentini Pisam occupassent, illud Florentiam translatum est, unde vulgo appellatur exemplar Florentinum, quod omnes peregrini illic invisere solent'. 
and added an unprompted coda on the state of learning. He touched upon the emergence of French universities and the study of Avicenna and Averroes. ${ }^{77}$ In his judgment, 'the arts were now flourishing (artes efflorescebant); clerics taught theology, and the philosophy of Aristotle, jurisprudence from Roman law, and medicine under the name of physic, to such a degree that they obtained all chairs. ${ }^{78}$ Even though the Leiden professor hardly endorsed all aspects of the medieval curriculum, or all the ways the Middle Ages had appropriated ancient learning, he helped canonize a story of medieval efflorescence, while recognizing its legacy in the traditions of university life that still marked his own world.

Although he hedged his assessments of the later Middle Ages, Perizonius cast all ambiguity aside when he reached the beginning of what later scholars would trumpet as the capital-R Renaissance-i.e., fourteenth- and fifteenthcentury Italian humanism. Today we are likely more familiar with how nineteenth-century historians like Jacob Burckhardt, or even eighteenthcentury figures like Voltaire, christened this Italian world a moment of cultural awakening. However, although their contributions are now comparatively neglected, late humanist scholars-of which Jacob Perizonius is a particularly late representative - did much to codify this narrative of the foundations of modern learning. And they articulated it through one of the oldest forms of historical narrative itself, historia universalis.

Perizonius reserved pride of place in this story for Petrarch. Although Tursellinus had characterized Petrarch as a celebrated writer, the Jesuit had not explicitly accorded broader cultural import to the trecento luminary ${ }^{79}$ Perizonius, in contrast, could not have been clearer. Glossing Tursellinus's reference to Franciscus Petrarcha, he remarked that Petrarch, crowned poet laureate at Rome, was 'the first to excel again' in literary acumen. But while Petrarch marked a tipping point, he was not without precedent in Italy. After Dante, so Perizonius declared while echoing his earlier use of reviviscere aliquantulum,

77 Leiden ms Perizonius Q 109, Vol. VIII, 86: 'Hoc saeculo duae Academiae in Gallia, Tholosana et Aurelianensis institutae sunt, ubi Iurisprudentia floruit, et Montispeliensis paulo post maxime medicinae dicata, quia hanc debebant maxime Avicennae et Averroes discipulis Saracenis, quia urbs mons Pessulanus sita in finibus Galliae et Hispaniae, cum s. Arabenis commercium exercebat'.

78 Leiden ms Perizonius Q 109, Vol. VIII, 86: 'Iam artes efflorescebant; Clerici docebant Theologiam, et Philosophiam Aristotelis, Iurisprudentiam ex Iure Canonico, Medicinam sub nomine physicae, adeo ut omnes cathedras obtinerent'.

Cf. Tursellinus, Epitome, 415 . 
'learning was restored little by little (paulatim studia restituta)' 80 Nor was Petrarch ahead of his time only in learning. Perizonius simultaneously linked him to proto-Protestantism, another of modernity's purported sources. As he maintained, Petrarch in his letters 'inveighed most harshly against the pope and the mores of the clergy-more than any Protestant'. ${ }^{81}$

In his treatise De doctrinae studiis, Perizonius offered a fuller paean to Petrarch and his Italian humanist milieu. He asserted the central place of Tuscany and Florence in the revival of 'humane letters', and he praised the renewed study of 'antiquity and eloquence and the Greek and Latin languages'. In this world, 'dry and confused disputations' gave way to 'plainly more solid forms of learning, dug up anew from the works of the ancients'. By conjuring this image of the works of the ancients or veteres once submerged but now 'dug up anew' (denuo eruebantur), Perizonius confirmed the old humanist trope of cultural renewal via ancient texts, ${ }^{82}$ and named Petrarch the star of this revival. ${ }^{83}$ Of course, Perizonius was hardly the first to credit him with inaugurating a new epoch. Along with Dante, Boccaccio, and others, Petrarch had enjoyed a privileged status in literary history since as early as the quattrocento. Leonardo Bruni

8o Leiden ms Perizonius Q 109, Vol. IX, 62: 'Franciscum Petrarcham. Primum ingenium excolere coepit, et cum factus poeta Laureatus...Petrarcha hic primum iterum ingenii dotibus et scriptionis excelluit, nam post Dantem Aldigerium ingenium exercere coepit, sicque paulatim studia restituta'.

81 Leiden ms Perizonius Q 109, Vol. Ix, 62: 'Hinc Petrarcha postea in epistolis suis acerrime in papam et clericorum mores invectus magis quam ullus protestantium'.

82 Perizonius, De doctrinae studiis, 15-16: 'Etenim quum viderent ingeniosi homines, tantum diligentiae rebus maximam partem obscuris et nugatoriis impendi, et tamen amplissimum ei a reliquis statui pretium, coeperunt istis honoribus excitati paulatim progredi longius, atque animum ad Antiquitatis quoque et Eloquentiae ac Linguarum Graecae Latinaeque studia sedulo applicare. Ita vero mox non amplius jejunis illis et implicitis incubuerunt disputationibus, sed jam solidioribus plane Doctrinis, quae ex Veterum operibus denuo eruebantur, dein ipsius elocutionis elegantia, Oratoriaeque ac Poeticae facultatis exercitio frequenti, excoluerunt plerique ingenium instruxeruntque. Viam his bonarum Artium incrementis munivit Etruria potissimum, et quae caput ejus est, Florentina Urbs. Ea enim ut paulo ante Accursium, praecipuum tunc Jurisprudentiae Lumen, ita mox etiam Dantem Aligerium, politissimae mentis Virum, progenuit, qui saeculo quarto decimo ineunte Humanioribus Literis tandem exorituris de integro, sua venustate quasi prolusit'.

83 Perizonius, De doctrinae studiis, 16: 'Vestigiis ejus institit, sed longe jam eruditior, Franc. Petrarcha, Aretii quidem, verum ex Florentinis itidem parentibus, natus, per factiones civiles patriam exilio mutare coactis. Divinum fuit incomparabilis Viri ingenium, diligentia et elegantiorum literarum amor summus, egregia item laborum ejus monumenta, ac de disciplinis liberalibus merita'. 
wrote a vita of Petrarch that praised his revival of classical learning. A century later, Christophe Milieu and other sixteenth-century pioneers of historia literaria continued to proclaim Dante and Petrarch's signal roles in the revival of letters. ${ }^{84}$ For instance, in Milieu's estimation, Dante and Petrarch emerged triumphant out of 'the densest darkness of the times, in which all things had been oppressed'. By the time the Leiden professor lectured his students, this foundation myth of the Renaissance had trickled down through several centuries of humanist scholarship, and Perizonius embraced it as a given..$^{85}$

A few pages after its evocative characterization of ancient learning excavated anew, Perizonius's De doctrinae studiis again invoked the term aliquantulum: 'the path to the delights of humane letters was now opened a little' (aliquantulum aperta). Renaissance and renewal became self-fulfilling prophecies: 'There was no delay, but immediately in the same century and the beginning of the next, illustrious names emerged in great number'. Perizonius rattled off a selection of these, including Boccaccio, Poggio, Biondo, Bruni, Valla and others. ${ }^{86}$ This chronology mirrored that of his universal history lectures. When discussing the causes of the Italian Renaissance, there he invoked such common tropes as the translatio studii supposedly set in motion by the migration of Byzantine scholars to Italy. He praised one of the most famous of these émigrés, Manuel Chrysoloras, for teaching Greek letters; thanks to his work, 'barbarism began to be expelled' (barbaries depelli coepta). ${ }^{87}$ With this

84 See Milieu, De scribenda universitatis rerum historia, 300: 'Primus namque e densissimis temporum tenebris, quibus omnia erant oppressa, Dantem praeceptorem, scriptis utraque lingua Latina et uulgari inclarescentem, proxime secutus Franc. Petrarcha, excussis Italicis Bibliothecis, incognitos ac neglectos ueterum Latini sermonis libros in medium legendos protulit, soluta et numeris astricta oratione, paulum se erigens ab ea obscuritatis literarum humilitate: ea erat ingenii uis et celeritas, ut multorum scriptorum productis testimoniis, eruditius in omni uarietate morum et accuratius, sermonis iam habita ratione, quam superiores scripserit'. For Milieu's treatment of Petrarch, see discussion at Kelley, 'Writing Cultural History', $355^{-6 .}$

85 For a survey of the history of notions of the Renaissance, see for instance Wallace Ferguson, The Renaissance in Historical Thought: Five Centuries of Interpretation (Cambridge, MA, 1948).

86 Perizonius, De doctrinae studiis, 20: 'Ita vero ad Humaniorum Literarum delicias via jam aliquantulum aperta, certatim istis deinceps studiis incubuere quamplurimi. Neque ulla fuit mora, quin eodem statim saeculo et proximi initio emergerent magno numero illustria nomina, Joh. Boccacius, Franc. Philelphus, Leonardus Aretinus, Florentinus ille Poggius, Guarinus Veronensis, Antonius Panormita, Laur. Valla, Flavius Blondus, Bartholomaeus Facius, aliique complures, quos enumerare omnes longum nimis foret'.

87 Leiden ms Perizonius Q 109, Vol. IX, 95: 'Chrysoloras: missus ab imperatore Graeco ad auxilium petendum mansit in Italia, et concilio Constanciensi interfuit, et literas Graecas docuit, sicque notitia antiquitatis aliqua orta barbaries depelli coepta'. 
brief phrase, Perizonius once more invoked beginnings: all the way from the twelfth century to the fifteenth, he described learning in states of becoming, not of being - not unlike those ages of infancy and youth that preceded the robust maturity he had located in Augustan Rome. Here Perizonius elaborated upon Tursellinus's own observation. The Jesuit had also singled out Chrysoloras for bringing Greek back to Italy, adding that 'not long afterwards, the Latin language - although it was growing wild - began to be improved (excoli coepta) ${ }^{\prime 8}$ Perizonius attached still wider significance to this beginning, crediting it with nothing less than the repulsion of barbarism (barbaries depelli coepta). Intriguingly, Perizonius likewise used a variation on this formulation in the aforementioned long title of his De doctrinae studiis, where he celebrated the Renaissance cultivation of doctrina after it had expelled barbarism or post depulsam Barbariem.

From these Italian beginnings, Perizonius traced the revival of arts and letters northwards across the Alps. Arriving much closer to home, he offered a brief yet evocative note on Jan and Hubert Van Eyck, those 'celebrated painters' who first mixed oil and colors. ${ }^{89}$ When discussing the origins of printing, he again invoked the spirit of nostra Europa he had first conjured in his glosses on the Carolingian epoch. Although he acknowledged that China had already developed forms of printing, he noted that the 'glory of having invented the typographic art (artis Typographicae)' had sparked priority disputes among various European cities that sought to claim the technology as their own. ${ }^{90}$ Through its allusion to Chinese printing technology, Perizonius's universal history showed hints of a newfound global dimension. ${ }^{91}$ But a few glosses later, he turned back to Italy and the theme of libraries and manuscripts woven throughout his treatment of the Middle Ages, from Corvey to Amalfi. Now he praised the famous Medici Library, which Lorenzo de' Medici adorned with

88 Tursellinus, Epitome, 434: 'Eadem tempestate Paulus Venetus extitit, et Chrysoloras Graecas litteras in Italiam reuexit. Nec ita multo post Latina lingua cum syluesceret, excoli coepta'.

89 Leiden ms Perizonius Q 109, Vol. X, 4: 'H.T. vixerunt Brugis in Flandria duo fratres Ioannes et Hubert van Eijk celebres pictores, qui primi oleum e lini semine coloribus miscere potuerunt, quum antea aquam tantum tingerentur: picturae eorum deinceps magno in pretio fuerunt'.

90 Leiden ms Perizonius Q 109, Vol. X, 20: 'Ars haec imprimendi iamdudum nota fuit Genuensibus sed in Europa de gloria inventae huius artis Typographicae litigunt, Harlemenses, Argentoratus, Moguntiaci'.

91 For an example of some of the new varieties of 'global' history practiced in Leiden contexts in the late seventeenth century, see for instance Georgius Hornius, Arca Noe, sive historia imperiorum et regnorum a condito orbe ad nostra tempora (Leiden, 1666). 
the 'rarest manuscripts and codices'. Such was the extent of Lorenzo's efforts, so Perizonius marveled, that the Medici collection 'still surpasses all other libraries. ${ }^{92}$

In the final portions of his final volume, Perizonius turned to the sixteenth century, which (as discussed above) he elsewhere labeled the onset of modern history or historia novissima. He praised Erasmus-just as he had Petrarchas a harbinger of Protestantism: 'among other forerunners of the Reformation (praecursores reformationis) the celebrated Erasmus of Rotterdam lived at this time. ${ }^{93} \mathrm{He}$ also made sure to mention how Erasmus relocated to Basel after arousing clerical odium in Louvain. Shortly thereafter, he arrived at the Reformation itself. Now the contrast between Perizonius and Tursellinus could not have been sharper. Perhaps no gloss better illustrates how a commentator could thoroughly transform the narrative of an auctor, especially in so labile a genre as historia universalis. Tursellinus had treated Luther with pointed brevity, noting in a terse aside how he began 'to rage' (debacchari) against the Pope. He then swiftly moved on to Ignatius of Loyola's founding of the Society of Jesus-'a new cohort of pious men' established to combat 'impious deserters of the faith' like Luther. ${ }^{94}$ Perizonius used Tursellinus's reference to Martinus Lutherus to tell a decidedly different story. At the beginning of a lengthy gloss on the emergence of Protestantism, he announced 'this is the most illustrious history of the Reformation (illustrissima historia reformationis), which arose in Germany in 1518 from this Luther. ${ }^{95}$ With this, the Leiden scholar reached the world he would sketch in his printed Commentarii historici on modern Europe. For Perizonius, nostra Europa had finally beaten back barbarism, superstition, and darkness, or at least so it seemed in retrospect.

92 Leiden Ms Perizonius Q 109, Vol. x, 32: 'H.T. Iam obtinebat summam auctoritatem in Republica Florentinorum Laurentius Medicaeus celebris eo nomine, quod condidit bibliothecam Florentinam, quam conquisitis per missos homines in Graeciam iam Turcis subiectam rarissimis manuscriptis et codicibus ornavit, quibus adhuc proinde omnes alias bibliothecas praecellit'.

93 Leiden ms Perizonius Q 109, Vol. X, 49: 'Vixit et H.T. inter alios praecursores reformationis ille celebris Erasmus Rotterodamensis, ibi natus e matre Gandava, sed pater incertus est, studiis addictus iis aliquamdiu in academia Lovaniensi operam dedit, sed ibi venit in odium clericorum, quare se Basileam contulit'.

94 Tursellinus, Epitome, 467: 'Porro Martinus Lutherus aduersus Rom. Pontificem debacchari in Saxonia, unde ipse erat, coepit. Saxoniae Duce fauente; et Ignatius Loiola, qui deinde Societatis Iesu auctor fuit, sanctimoniae fama florere coepit, Deo nouam piorum hominum cohortem, aduersus impios fidei desertores parante'.

95 Leiden ms Perizonius Q 109, Vol. X, 53: 'Porro Martinus Lutherus: Haec est illustrissima historia reformationis, quae anno 1518 coepit ab hoc Luthero in Germania'. 


\section{Conclusion: Historia Universalis as Via Media between Past and Present}

From the end of paganism to the beginning of Protestantism, from Charlemagne to Charles v, Perizonius retold many stories that had already been rehearsed multiple times before the turn of the eighteenth century. Granted, few of their individual components were particularly new, and various narratives of Renaissance, Reformation, and the like had already been voiced while such cultural moments were still very much ongoing. But Perizonius and other scholars around 1700 worked with both the benefits and the blinders of hindsight; when they described the transition from the Middle Ages to modernity, they described a series of developments that were now recognized as definitively past, if just recently so. Whether or not they agreed upon what modernity was, they often defined it-even in the simplest of pedagogical exercises-through ancient genres and ancient categories. And no one of these ancient tools proved more capacious than historia universalis itself. Universal history promised a union of antiquity and modernity, which Perizonius saw as a solution to those conflicts and quarrels that so divided his contemporaries.

In a revealing passage of his De doctrinae studiis, Perizonius put this union into action. As he warned, history threatened to repeat itself. Just as the artes liberales had sunk from the heights of the Augustan Golden Age into barbarism and corruption only to be revived more than a millennium later by figures as diverse as Petrarch, Erasmus, and Scaliger, so perhaps the new Golden Age had likewise ended. In Perizonius's mournful estimation, his own times resembled the time 'immediately following the Augustan age,' in which, according to Seneca, many Romans 'built libraries with as many volumes as possible', but still absorbed almost no learning. ${ }^{96}$ Like the Rome of Seneca, the decades around 1700 seemed redolent of autumnal lateness. They threatened the repetition of that drama that had ultimately resulted in antiquity's end.

Yet this story of decline was not merely a story of negation. Rather, it was precisely this constant threat of decline that gave such force to Perizonius's account of the revival of learning in the transition from the Middle Ages to modernity. Later in the eighteenth century, philosophes like D'Alembert would depict the stages of early modern cultural revival—consigned to such categories

96 Perizonius, De doctrinae studiis, 44: 'Exhibemus denuo et repraesentamus saeculum Augusteo proximum, quo, ut Seneca nobis narrat, instruebant multi Bibliothecas voluminibus quam plurimis, sed nulla fere doctrina pectus, licet et tunc ea paratu esset facillima, quum itidem paulo ante illustrium ingeniorum ope floruisset quam maxime. Cf. Seneca, De tranquillitate animae 9.4. 
as erudition or belles-lettres - as necessary prologues to true Enlightenment, yet prologues nonetheless. Their story of progress culminated not in sixteenthand seventeenth-century erudition, but rather in the philosophy of their own day. Still, this narrative required identification of the humanistic artes liberales as agents of modernity - an identification codified by Perizonius and his fellow members of the Latinate Republic of Letters in the decades around $1700 .{ }^{97}$ Ironically, even if Perizonius and others bequeathed a framework of periodization to the Enlightenment, fashioned out of historia universalis, their version of the story contained a far less sanguine coda. Theirs was not a narrative of unmitigated progress. If anything it was the opposite, even if Enlightenment narrators of historical progress would go on to craft their own triumphalist accounts of historia novissima from now neglected late humanist precedents.

Having examined Perizonius's glosses on universal history, we can now see how the Leiden professor's insistence on the present-day decline of the artes liberales informed his far more famous critique of historical Pyrrhonism. Perizonius read the fashion for Pyrrhonism as a sorry consequence of the fall of learning and letters from the heights of humanistic scholarship. If one did not possess the learned tools to place an ancient text in its own context, or compare that context to other pasts, one risked indulgence in overhasty dismissals of historical truth writ large. In his De fide historiarum, Perizonius instead proposed a middle course between credulity and skepticism. In the same treatise he also identified universal history as another via media-i.e., a middle path in the realm of pedagogy between two seemingly irreconcilable camps: those who valued the study of Greco-Roman antiquity above all else, and those who possessed a presentist faith in the utility of modernity alone. He argued that all history, whether ancient or modern, ought to be combined into a 'perpetual course (perpetuum cursum) of historical studies,' declaring, 'this is that middle way (media illa via) for me'. He thereafter described the views of the two respective camps, and their attendant limitations. The partisans of antiquity were:

Those who read the Greeks and Romans so much, and wish all knowledge of histories to be contained within the flourishing age of those peoples, while they not only ignore, but also do not desire to know the surviving events of the Middle Ages and more recent times, or indeed the history of our fatherland, and the origins, progress, fates, and particular mutations of now illustrious peoples; rather they completely reject and spurn such topics. 
Yet this narrowness was just as harmful when it came from the opposite temporal direction. Next, Perizonius condemned those who,

Neither understand ancient things, nor labor to understand them, maintaining instead that it is enough if they should have learned the peoples and princes of the latest age (ultimi aevi), either from Charles v, or perhaps from the origin of the Golden Law, or the Bulla, as it is called, and now the public law of Germany, or at most from Charlemagne, and explored the conflicts and pacts, wars and alliances between them.

In Perizonius's estimation, this was a quarrel of the ancients and the moderns best solved by combining both antiquity and modernity into a truly universal history:

But how much better would things be if the second group did not spurn more ancient histories, and the first did not spurn more recent matters, and if they joined all things together, as is right, and committed to memory the course of history, all the way from the creation of the world to these times, as if expressed in a brief table, and held it deep within their hearts. ${ }^{98}$

Perizonius did not just advocate this sweeping act of union; rather, he practiced it, in the unlikely form of years of lecturing upon a Jesuit epitome at the University of Leiden. As he made clear to his students, antiquity and

98 Perizonius, De fide historiarum, 4: 'Haec mihi est, Auditores, media illa via, quam insistere omnes velim potius, quam ut per alterutram unice semitam perpetuum studiorum Historicorum instituant cursum. Sed longius etiam ab se invicem in contraria secedunt omnia, quum Hi, qui Graecos tantum legunt et Romanos, omnemque Historiarum scientiam intra florentem istarum gentium aetatem contineri volunt, at reliquas medii et postremi temporis res gestas, Patriae immo, et illustrium nunc Populorum, origines, progressus, fata, ac praecipuas rerum mutationes, non modo ignorant plane, sed neque scire desiderant, immo rejiciunt penitus et explodunt: tum vero Illi, qui e contrario antiqua inscito prorsus negligunt fastidio, neque intelligunt ea, aut intelligere laborant, satis videlicet habentes, si ultimi aevi inde a Carolo v. vel forsan ab Aureae Legis, seu Bullae, ut vocatur, ac publici nunc Germaniae Juris, origine, vel summum a Carolo M. usque, Populos et Principes cognorint, eorumque controversias inter se et pactiones, bella et foedera, habeant explorata. At quanto rectius facerent utrique, si neque hi aspernarentur antiquiora, neque recentiora illi: si jungerent omnia, ut oportebat, et qualemcunque rerum ab Orbe condito ad haec usque tempora seriem, brevi quasi tabella expressam, mandarent memoriae, ac pectore suo penitus conditam tenerent'. 
modernity stood in dialectical relationship to one another; the latter could not be understood without reference to the former. His notion of modernity-and its seeming fragility—depended upon an increasingly tenuous remembrance of that 'flourishing age' of Greco-Roman antiquity. To this scholar of historia antiqua, historia novissima had begun in the recent past, with the revival of ancient learning in the prior two centuries. Perizonius's periodization depended upon recognition of the world we now awkwardly label 'early modern' as simultaneously foreign and familiar, finished and unfinished. This paradox was best understood through the ancient genre of historia universalis, which the Leiden scholar embraced as a constantly expanding via media between past and present. Historia universalis enabled him to speak of nostra Europa in the first-person plural, and to link its varied fortunes to both the life and afterlife of the ancient world. 